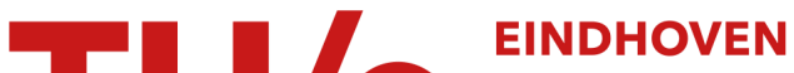 \\ UNIVERSITY OF \\ TECHNOLOGY
}

\section{Techniques for flexible radio-over-fibre networks}

Citation for published version (APA):

Koonen, A. M. J., Jung, H. D., Yang, H., Okonkwo, C. M., Zheng, Y., Abraha, S. T., \& Tangdiongga, E. (2009). Techniques for flexible radio-over-fibre networks. In International Conference on Photonics in Switching, 2009. PS '09. 15-20 September 2009, Pisa, Italy (pp. 1-4). Institute of Electrical and Electronics Engineers. https://doi.org/10.1109/PS.2009.5307753

DOI:

10.1109/PS.2009.5307753

Document status and date:

Published: 01/01/2009

\section{Document Version:}

Publisher's PDF, also known as Version of Record (includes final page, issue and volume numbers)

\section{Please check the document version of this publication:}

- A submitted manuscript is the version of the article upon submission and before peer-review. There can be important differences between the submitted version and the official published version of record. People interested in the research are advised to contact the author for the final version of the publication, or visit the $\mathrm{DOI}$ to the publisher's website.

- The final author version and the galley proof are versions of the publication after peer review.

- The final published version features the final layout of the paper including the volume, issue and page numbers.

Link to publication

\section{General rights}

Copyright and moral rights for the publications made accessible in the public portal are retained by the authors and/or other copyright owners and it is a condition of accessing publications that users recognise and abide by the legal requirements associated with these rights.

- Users may download and print one copy of any publication from the public portal for the purpose of private study or research.

- You may not further distribute the material or use it for any profit-making activity or commercial gain

- You may freely distribute the URL identifying the publication in the public portal.

If the publication is distributed under the terms of Article $25 \mathrm{fa}$ of the Dutch Copyright Act, indicated by the "Taverne" license above, please follow below link for the End User Agreement:

www.tue.nl/taverne

Take down policy

If you believe that this document breaches copyright please contact us at:

openaccess@tue.nl

providing details and we will investigate your claim. 


\title{
Techniques for Flexible Radio-over-Fibre Networks
}

\author{
Ton Koonen, Hyun-Do Jung, Hejie Yang, Chigo Okonkwo, Youbin Zheng, \\ Solomon Tesfay Abraha, Eduward Tangdiongga
}

\author{
COBRA Institute, Eindhoven University of Technology, Eindhoven, The Netherlands \\ a.m.j.koonen@tue.nl
}

\begin{abstract}
Radio-over-fibre systems can efficiently deliver broadband wireless services in access and in-building networks. RoF signal transport and routing techniques are presented which are robust against fibre dispersion and provide capacity-on-demand for high-capacity multi-tone radio signals
\end{abstract}

Keywords: Radio-over-Fibre, broadband wireless service, access network, in-building network, optical routing

\section{Introduction}

People have a growing need to be on-line wherever they are, in order to browse the internet, read their e-mails, exchange data files, etc. Hence telecommunication networks need to be able to provide wireless broadband services everywhere, preferably by carrying these in overlay over the same network infrastructure on which they are already transporting their wired services. In the public access domain, an UMTS base station can serve users within a cell of several $\mathrm{km}$-s in diameter, and can provide wireless data services up to $2 \mathrm{Mbit} / \mathrm{s}$. Inside buildings, an WLAN IEEE $802.11 \mathrm{~g}$ system may cover a cell containing multiple rooms within a reach up to tens of meters, and can provide up to $54 \mathrm{Mbit} / \mathrm{s}$. Those limited data rates have to be shared among the many users which potentially may be within a cell, hence the data rate available per user may be small and will heavily depend on the traffic loads generated by the other users in the same cell. By shrinking the cell size and increasing the wireless data rate, less users have to be served out of a larger capacity. Thus, by introducing so-called radio pico-cells the capacity per user can be significantly increased. Moreover, within such a pico-cell less users have to compete for capacity, hence the availability will be improved. An outdoor pico-cell may be constituted by an antenna creating a fixed wireless access connection in the access network (e.g. a radio beam directed to a few houses), and an indoor pico-cell by a microwave antenna covering a room.

The increased system complexity incurred with pico-cell architectures can be reduced by deploying radio-over-fibre (RoF) techniques, where the generation and modulation of the microwave signals is done at a central site, from where by means of optical fibre the signals are distributed to the simplified antenna stations.

Due to the reduced cell size, the number of users in a picocell may vary much more than in a UMTS or WLAN cell. Dimensioning the system such that it provides each picocell continuously with the maximum capacity it may need may lead to excessive overprovisioning and thus an excessive amount of system resources needed. Dynamic provisioning of capacity to each cell, i.e. just-in-time delivery of the capacity which is actually needed, can significantly improve the operation efficiency of the system.

In this paper, we report on flexible RoF systems, in which a combination of dispersion-robust RoF techniques and dynamic optical routing are deployed in order to achieve this dynamic wireless capacity provisioning.

\section{The Optical Frequency Multiplying technique}

Flexibly reconfiguring RoF networks implies that the link lengths along which the RoF signals have to travel may vary sizeably. Hence the RoF system should be able to handle a widely varying fibre dispersion. In access networks, the system notably has to deal with the chromatic dispersion in SMF, and in in-building networks there is a great challenge to overcome the modal dispersion occurring in multimode silica (or polymer) optical fibre. Our Optical Frequency Multiplying (OFM) RoF technique has been shown to be robust against both of these dispersion types [1].

Central Station

Radio Access Point

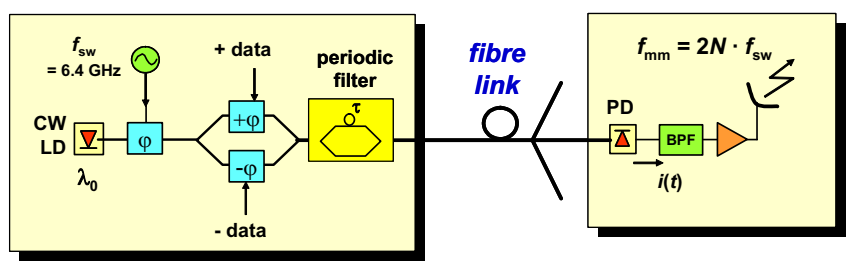

Fig. 1 Optical Freqency Multiplying

As shown in Fig. 1 , it is based on periodically sweeping the optical frequency of a light source in the Central Station (CS), followed by FM-to-IM conversion in an interferometric filter (e.g. an MZI). After intensity detection in the simplified Radio Access Point (RAP), the output signal of the photodiode (PD) contains many harmonics of the sweep frequency, and one of these can be selected by an electrical bandpass filter (BPF) as the desired microwave signal, which subsequently is amplified and radiated by the antenna. It has been shown that the purity of the obtained microwave signal is determined by the phase noise of the sweep generator in the CS, and is not affected by the phase noise of the laser diode. As this sweep generator can be shared by multiple RAP-s, its higher costs associated with a low phase noise performance will not have a large impact on the costs per RAP. Microwave linewidths of less than $1 \mathrm{kHz}$ have been obtained at frequencies beyond $30 \mathrm{GHz}$; this allows comprehensive high-capacity wireless signal modulation formats such as quadrature amplitude modulation (QAM) schemes. Also it has been shown that the signal transmission is very robust 
against chromatic dispersion in SMF; Fig. 2 [2] shows the fading dips which occur with double-sideband intensity modulation (IM-DSB), while our OFM technique clearly avoids these dips. Using OFM, we showed the successful transmission of 16-QAM and 64-QAM radio signals up to $20 \mathrm{Msymbols} / \mathrm{s}$ (so up to 80 and $120 \mathrm{Mbit} / \mathrm{s}$ ) at $39.9 \mathrm{GHz}$ over up to $25 \mathrm{~km}$ of SMF in the $1310 \mathrm{~nm}$ wavelength band [3].

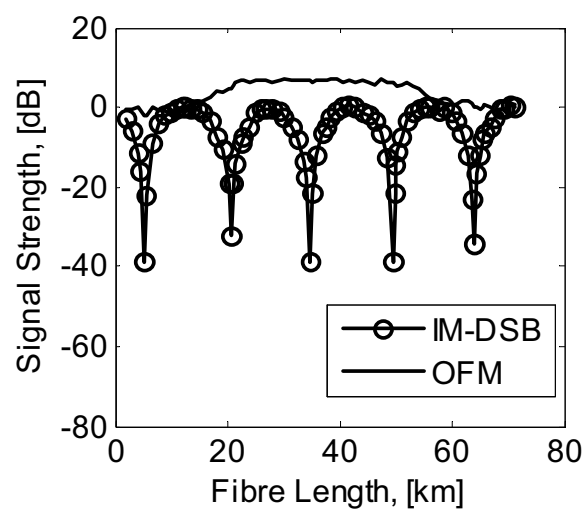

Fig. 2 Impact of SMF dispersion on the delivery of a 22GHz RoF signal, with IM double-sideband modulation and with OFM (fibre losses are not taken into account)

Also modal dispersion in multimode fibre can be overcome by our OFM technique. Successful transmission has been demonstrated of 16-QAM and 64-QAM signals up to 120 $\mathrm{Mbit} / \mathrm{s}$ in the $24-30 \mathrm{GHz}$ band over $4.4 \mathrm{~km}$ silica $50 \mu \mathrm{m}$ core graded-index fibre [4]. In addition, we succeeded in handling multitone wireless signals, by transmitting $210 \mathrm{Mbit} / \mathrm{s}$ 64-QAM over the same fibre link by using up to 10 subcarriers [5].

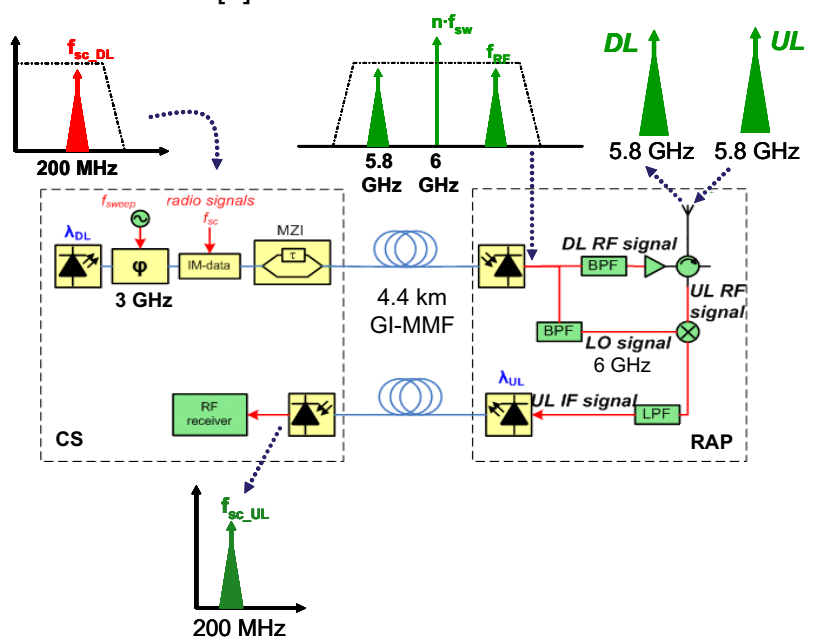

Fig. 3 Bi-directional OFM system with remote LO delivery

Next to downstream microwave signal delivery, the OFM technique can also facilitate the remote delivery of a local oscillator (LO) signal to the RAP. As illustrated by Fig. 3, bidirectional transmission has been shown over $4.4 \mathrm{~km}$ graded-index silica fibre with a 24Mbit/s 64-QAM downstream signal at a subcarrier of $200 \mathrm{MHz}$ which is upconverted to $5.8 \mathrm{GHz}$ by the OFM technique, as depicted in Fig. 3. The $24 \mathrm{Mbit} / \mathrm{s} 64-\mathrm{QAM}$ upstream signal at $5.8 \mathrm{GHz}$ is downconverted to an IF of $200 \mathrm{MHz}$ by using the remotely generated $6 \mathrm{GHz} \mathrm{LO}$ signal, and sent upstream using a relatively low-frequency FP laser diode. Also bidirectional transmission of $100 \mathrm{Mbit} / \mathrm{s} 16-\mathrm{QAM}$ signals at $17.2 \mathrm{GHz}$ over 100 metres of $50 \mu \mathrm{m}$ graded-index POF has been shown [7].

When conveying wireless signals over fibre links, care should be taken that the wireless transmission protocols are still respected. E.g., in the IEEE 802.16 WiMAX protocol, the time-division-duplex communication takes place alternately in the downlink (DL) and uplink (UL) subframes, which are spaced by a time gap. In an RoF system setup, this time gap is enlarged by the round trip delay of the fibre link. Hence the DL and UL subframes become shorter, and the link throughput is decreased. However, for typical frame sizes it can be shown that this decrease is less than $1 \%$ provided that the fibre link length is less than 500 meters [1].
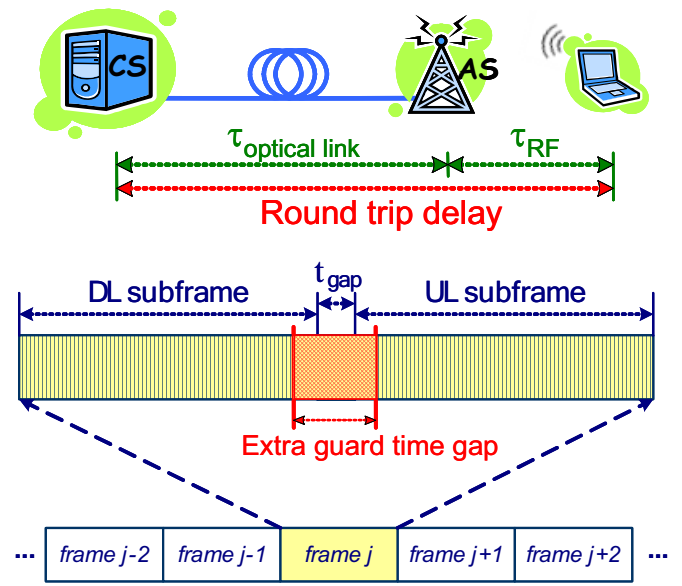

Fig. 4 Impact of RoF on handling of wireless protocols

Thus we have demonstrated the suitability of the OFM RoF technique for both outdoor SMF and indoor MMF/POF systems.

\section{Dynamic radio-over-fibre signal routing}

In a hybrid WDM-TDM Fibre-to-the-Home network, wavelength routing can provide dynamic allocation of capacity to the individual homes, and thus improve the operation efficiency of the system's resources. Similarly, wavelength routing in a Fixed Wireless Access (FWA) system may also improve its performance. As shown in Fig. 5 , along a ring-shaped fibre access network the various RoF signals may be dropped to local antenna stations by means of tunable optical add-drop nodes (ADN-s) [8]. An ADN may also only partially drop a wavelength signal, and drop the rest at one or more other ADN-s, thus realising multi-casting. As the same RoF signal then needs to travel through different fibre lengths, the dispersion-immunity of the OFM technique enables such multicasting schemes. 


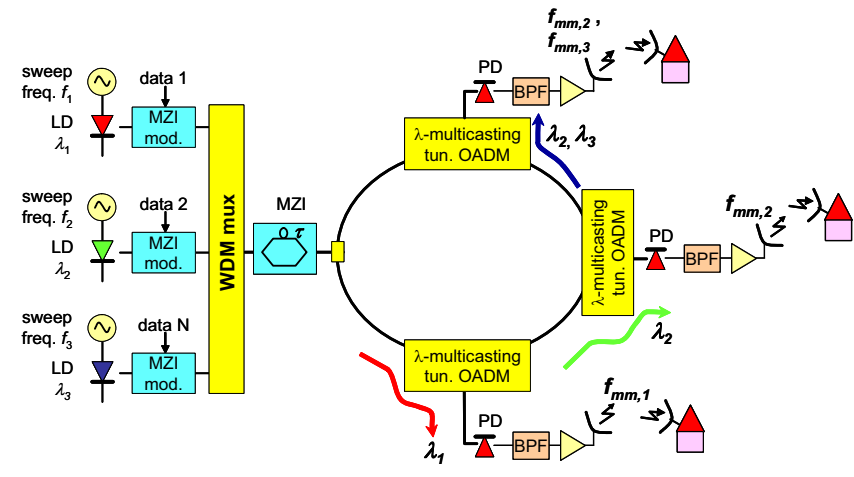

Fig. 5 Routing of RoF signals in an FWA network

As illustrated in Fig. 6 for an in-building wireless services scenario, dynamical routing of RoF signals may be done by means of optical routing in the add-drop nodes (ADN-s) feeding the RAP-s in a building.

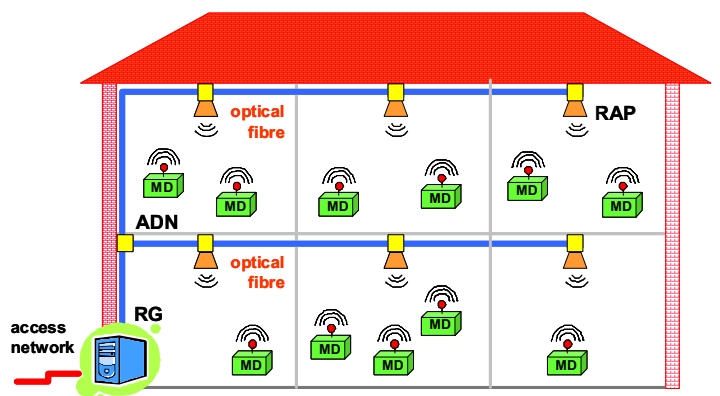

Fig. 6 Routing of radio-over-fiber signals (RN = routing node, $M D=$ mobile device)

Within the residential gateway (RG), the RoF signals can be distributed at various wavelengths, and a wavelengthselective ADN may drop the appropriate RoF signal to its RAP. We have demonstrated RoF routing in a silica graded-index MMF 3-node network using fixed multimode fibre Bragg gratings [9].
By tunable wavelength conversion of the RoF signal, within the RG the routing of the RoF signals can be set. Simultaneously converting an RoF signal to multiple wavelengths enables to do multicasting as well.

Based on the OFM technique, the tunable wavelength conversion can be implemented by replacing the intensity modulator in the conventional OFM configuration by crossgain modulation (XGM) in a semiconductor optical amplifier (SOA). As illustrated in Fig. 7, we have up-converted radio signals and changed the wavelength of the OFM-swept optical signal to a new wavelength simultaneously, where the new wavelength $\left(\lambda_{c w}\right)$ is provided by a local tunable $\mathrm{CW}$ optical source. This new wavelength can be selected according to the 'remote' address information extracted from the downstream optical signal, thus enabling remotely controlled routing. Using the OFM principle, the CW optical signal is phase-modulated by the RF sweep signal $\left(f_{S W}\right)$ to generate multiple optical harmonics. This phase-modulated optical signal $\left(\lambda_{c w}\right)$ is injected into the SOA together with the intensity-modulated $(\mathrm{IM})$ optical signal $\left(\lambda_{M O D}\right)$ carrying the radio signals from the $\mathrm{CS}$. By cross-gain modulation (XGM) in the SOA, the radio signal is duplicated onto the phase-modulated optical signal $\left(\lambda_{c w}\right)$. In the MZI, PM-IM conversion yields microwave carriers at multiples of the RF sweep frequency $\left(f_{S W}\right)$ to appear at the optical wavelength $\left(\lambda_{C W}\right)$ as illustrated in Fig. 7. The converted optical signal $\left(\lambda_{C W}\right)$ is routed by means of an AWG to each destination (room), where they are detected and the radio signal is selected by an electrical bandpass filter (BPF).

Fig. 8 shows the RF spectra of the input radio signal from $\mathrm{CS}$ and the up-converted radio signal routed to the destination, respectively. The input radio signal (64-QAM, $20 \mathrm{MSymbol} / \mathrm{s}, f_{R F}=3.6 \mathrm{GHz}$ ) in Fig. $8(\mathrm{a})$ is successfully optically up-converted along with the harmonics of $f_{S W}$ to $f_{U P}=n \bullet f_{S W} \pm f_{R F}=6 \cdot 6_{G H z} \pm 3.6_{G H z}$ (where $n$ is the order of harmonics) in Fig. 8(b). The SNR of the routed radio signal at $39.6 \mathrm{GHz}$ is reduced by around $16 \mathrm{~dB}$ and there is an EVM penalty of $2.5 \%$ as compared to the input radio signal. In addition, a nonlinear skirt slope appears at the edge of the signal band. This degradation comes from the ASE

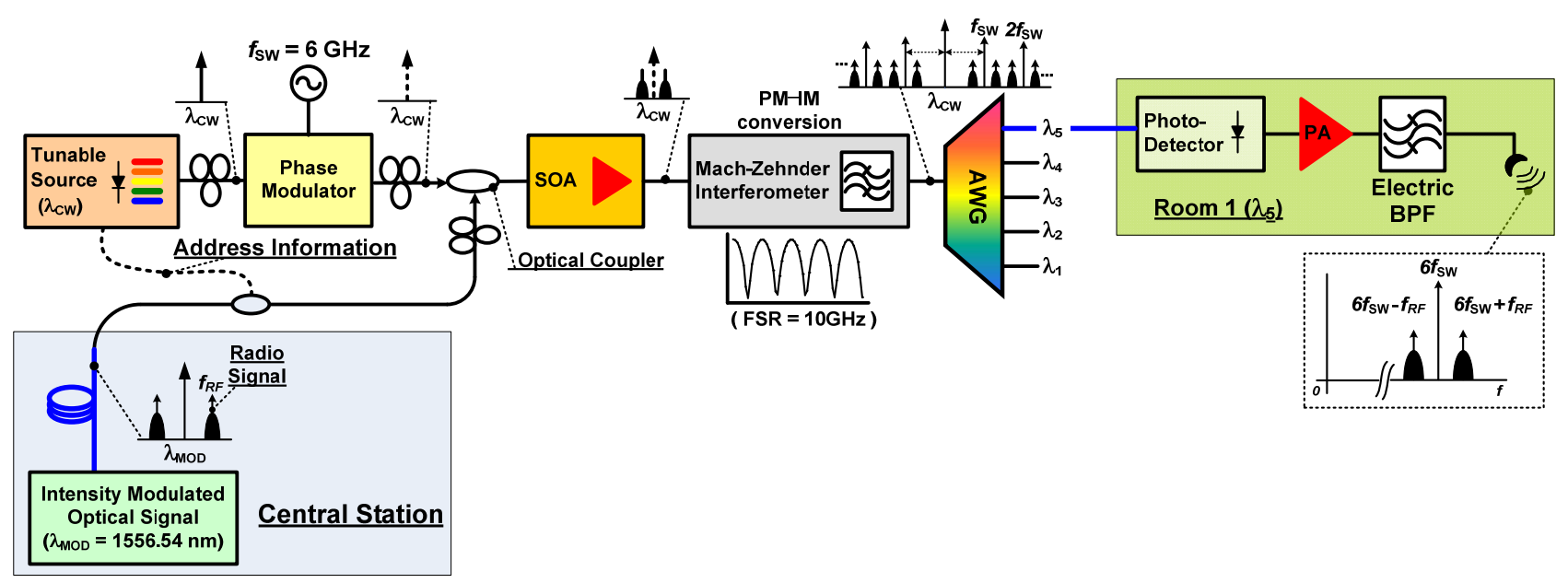

Fig. 7 OFM system configuration for the dynamic radio signal routing (AWG: arrayed waveguide grating; data format: $64-\mathrm{QAM}, 25 \mathrm{Msymbol} / \mathrm{s}$ at $500 \mathrm{MHz}$ IF carrier) 
noise of the SOA, the wavelength-conversion penalty, and the nonlinearity of the SOA gain profile. To evaluate the routing and up-conversion performance at different optical channels (wavelengths), we have measured the EVM of the routed channel $\left(\lambda_{c w}\right)$ as a function of the input optical power $\left(\lambda_{C w}\right)$ at the fixed IM optical power $\left(\lambda_{M O D}\right)$. As shown in Fig. 9, the performance of the routed microwave signals at each channel is nearly the same, with around 4.5\% EVM performance [6].

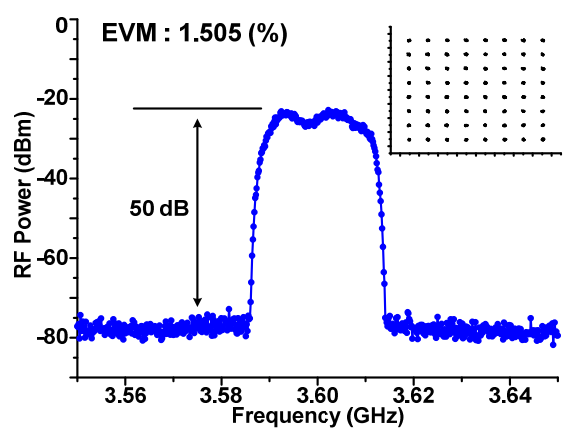

(a)

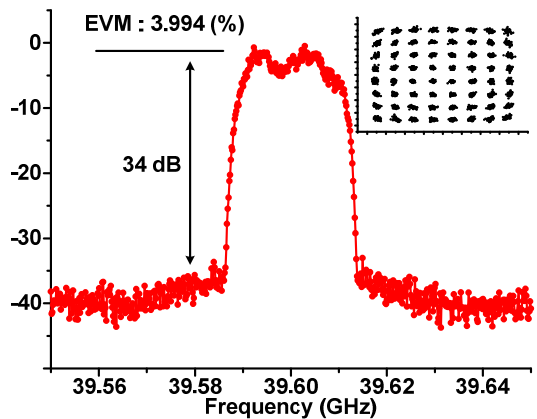

(b)

Fig. 8 RF spectra (a) input 64-QAM signal (20MS/s) at $3.6 \mathrm{GHz}$, (b) routed 64-QAM signal $(20 \mathrm{MS} / \mathrm{s})$ at $39.6 \mathrm{GHz}$ (Inset: constellation diagram)

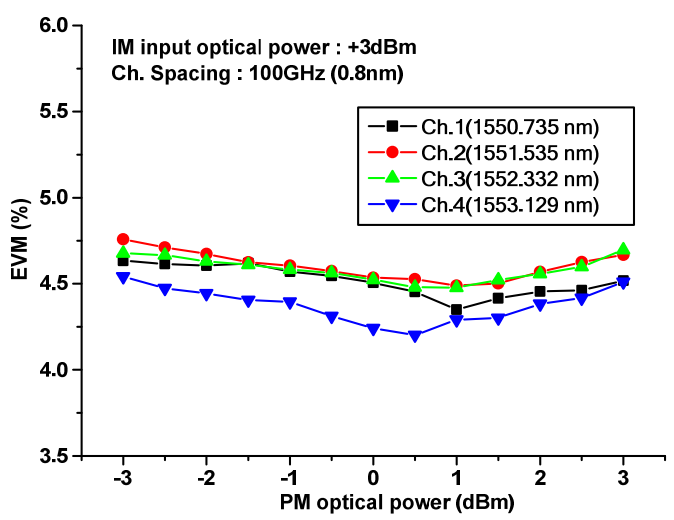

Fig. 9 Performance of up-converted radio signal at different optical channel (the power of input IM optical signal : $+3 \mathrm{dBm}$ )

\section{Conclusions}

The optical frequency multiplication technique is a promising approach for providing high-capacity wireless services over fibre in access and in-building networks. By means of optical routing in a point-to-multipoint network architecture, the fibre network can efficiently deliver wireless capacity on demand. Flexible routing of radioover-fibre signals can be realised with tunable wavelength converters in combination with passive wavelength adddrop modules.

\section{Acknowledgement}

Funding from the European Commission for this work performed in the FP7 projects ALPHA and BONE is gratefully acknowledged.

\section{References}

[1] A.M.J. Koonen, M. García Larrodé, "Radio-over-MMF Techniques - Part II: Microwave to Millimeter-Wave Systems", J. Lightw. Technol.,Vol. 26, No. 15, Aug. 2008, pp. 2396-2408

[2] A. Ng'Oma, G.-J. Rijckenberg, A.M.J. Koonen, "Building extended-reach radio-over-fibre links by exploiting optical frequency multiplications's dispersion tolerance", Proc. of IEEE MTT-S International Microwave Symposium (IMS 2007) 3-8 June 2007, Honolulu, Hawaii, pp. 2197-2200

[3] M. Garcia Larrode, A.M.J. Koonen, J.J. Vegas Olmos, E.J.M. Verdurmen, J.P. Turkiewicz, "Dispersion tolerant radio-overfibre transmission of 16 and 64 QAM radio signals at $40 \mathrm{GHz}$ ", Electron.Lett., Vol. 42, No. 15, pp. 872-874

[4] M. García Larrodé, A.M.J. Koonen, J.J. Vegas Olmos, "Transmission of microwave signals beyond the modal bandwidth of multimode fiber links", Proc. of Int. Top. Meeting on Microwave Phot., Grenoble, Oct. 3-6, 2006.

[5] H. Yang, E. Vos, H.-D. Jung, B. Huiszoon, J.H.C. van Zantvoort, A.M.J. Koonen, E. Tangdiongga, "Performance Evaluation of Radio-over-Fiber Systems for Multi-carrier Signals Employing Optical Frequency Multiplication", accepted for IEEE J. Lightw. Technol.

[6] M. Garcia Larrode, A.M.J. Koonen, J.J. Vegas Olmos, A. Ng'Oma: "Bidirectional radio-over-fiber-link employing optical frequency multiplication", IEEE Phot. Techn. Lett., Vol. 18, No. 1, pp. 241-243, Jan. 2006

[7] A. Ng'oma, J. Zeng, H.P.A. van den Boom, Y. Watanabe, A.M.J. Koonen, "Bi-directional polymer optical fiber-based system for distributing 100 Mbps WiMAX signals exceeding 17 GHz", Proc. AP-MWP, Jeju Island, S. Korea, Apr. 25-27, 2007

[8] A.M.J. Koonen, A. Ng'Oma, G.-J. Rijckenberg, M. Garcia Larrode, P.J. Urban, H. de Waardt, J. Yang, H. Yang, H.P.A. van den Boom, "How deep should fibre go into the access network?", Proc. of ECOC 2007, Berlin, paper Mo1.1.4 (4p.)

[9] M. García Larrodé, A.M.J. Koonen, "All-fiber full-duplex multimode wavelength-division-multiplexing network for radioover-multimode-fiber distribution of broadband wireless services", IEEE Trans. Microw. Theory Tech., Vol. 56, No. 1, Jan. 2008, pp. 248-255

[10] H.-D. Jung, C. Okonkwo, E. Tangdiongga, A.M.J. Koonen, "Optical Routing of Millimeter-Wave Signal with a New Optical Frequency Multiplication Scheme," Proc. EU-Workshop, Duisburg, May 18-20, 2009, paper Sep. 21-25, 2008, paper Tu.4.5 